\title{
The consultant's caseload: a working framework
}

\author{
Leonard Fagin, Doris Hollander and Malcolm Weller
}

\begin{abstract}
Consultants psychiatirists have a limilted time to offer thelr services. Current contracts, based on population norms, do not establish limits to consultionts' workload. Reorganisation of service proviston, itsing demands and marked social differences in diflerent localtites have brought these population norms into queetion. What is the desirable workload for a consultant to ensure a decent level of care to patients? A model is proposed that specifically applies to whole-time consultants within a cotchment area, and those working in adult eeneral poychlatry. If will need to be adopted for other speciallities. The figures given are estimates, which will need to be audited appropriately for refinement. It is hoped that such on anclyats will focilitate the process of purchasing care for specilic potient groups, and be a clearer way of lidentilying gaps in clinical service.
\end{abstract}

\section{Model and basic assumptions}

Consultants, as any person in a working environment, have a limited time to offer their services. Current contracts, based on population norms, do not establish limits to consultants' workload, who are expected to respond to all referrals arising out of the catchment area. Reorganisations of service provision, rising demands and marked social differences in various localities, especially in London boroughs, have brought these population norms into question. A more appropriate model, which circumvents any imperfections in weighted capitation formulae, should take into account the specific workload undertaken by each consultant, the particular patient characteristics of that workload, and the supportive infrastructure in each area. Similar views have been expressed in the USA (Goldman et al, 1994) and in this country (Watson, 1985, 1986; Creed, 1995). In times when consultants are asked to prioritise care, it is particularly relevant to assess the differential workload imposed by patients with varying diagnoses, so that this information can be passed on to purchasers when they are deciding what to purchase and for whom.

The following exercise specifically applies to whole-time consultants within a catchment area, and those working in adult general psychiatry. The model will need to be adapted for other specialities. The following figures are estimates, and are intended as illustrative examples, and therefore will need to be audited appropriately for refinement, but they have been produced after extensive consultation with colleagues in the North Thames Region. This paper is intended to help those involved in negotiating the provision of local services to specified quality levels. It is hoped that such an analysis will facilitate the process of purchasing care for specific patient groups, and be a clearer way of identifying gaps in clinical service. Within trusts, and applied to different specialisms, this model can generate discussion on apportionment of responsibilities and manpower requirements.

\section{Work hours}

Assuming an eleven session per week wholetime appointment (excluding time on duty), a typical consultant should spend the following time in non-clinically related activities per week. We accept that by breaking down the components of the job into separate areas we are not taking into account some degree of overlap and interdigitation of tasks but we have tried to bear this in mind by allocating time to each one of these activities and reducing them by $15 \%$. They are therefore conservative estimates. It should be pointed out that we do not believe that at the moment consultants spend the desired amount of time in research-related activities, mostly because of pressures of clinical work. It is also suggested that committee work is voluntary(l) and should be considered outside professional time, although we contend that with extra 
managerial responsibilities consultants should include this time as part of their core activities. Likewise, travelling has not been traditionally included within contracts, but it should be argued that with increasing dispersal of venues for psychiatric services, consultants and other professionals will be spending a substantial proportion of their working day getting from the acute unit to the locality mental health centre, from the community residential home to primary care settings, and so forth. Finally, we also are advised that contractually lunch breaks do not exist!

Taking into account that:

1 session $=3.5$ hours

and a full-time contract $=11$ sessions/week

Working hours per week $=3.5 \times 11=38.5$ hours per week.

If we divide non-clinical working hours into three broad categories, administration, research and teaching we estimate that the consultant will spend on average every week:

Administration (to include committee work. telephone calls, reading, corresponding. information meetings with management) Research (to include academic meetings and audit)

7 hours

3.5 hours

Teaching (to include supervision of juniors, other disciplines, formal/informal staff meetings, journal clubs, etc.)

Travelling (between bases) (at the moment non-contractual)

Totel

l

6 hours

4 hours

20.6 hour

This would leave a total of $38.5-20.5=18$ hours/week to dedicate to clinical activities.

After discounting holidays and study leave (8 weeks) the clinical time available over a period of one year would therefore come to:

$$
18 \times 44=792 \text { hours. }
$$

\section{Patient worlload}

The analysis assumes that the consultant has the support of a full-time junior doctor clerking and looking after his/her inpatients, as well as doing a limited amount of out-patient work, a full complement of nurses in-patient and community settings, and is closely working within a multidisciplinary team of social workers, psychologists, occupational therapists and other disciplines. It is worth bearing in mind that although some clinical work can be delegated, there are specific responsibilities, especially those duties under the Mental Health Act, which only the consultant can undertake. Time spent with particular groups of chronically ill patients will also depend on residential facilities and staff available in the locality. We have considered two scenarios: one where the consultant is always available and time is included to see the patient and relatives personally throughout the clinical intervention (the ideal), and a second one where the consultant delegates many of the tasks to his junior colleagues and other staff in the multiprofessional team (the alternative).

Not all patients take the same amount of clinical time and input from a consultant. The following are broad nosological categories we have used for this analysis, with some illustrative vignettes.

\section{(a) Psychosis}

(i) Young adult schizophrenic. Patient is likely to be still living with parents. His symptoms have brought him into trouble with the police. He abuses drugs. Parents are unable to handle situation any longer, and are asking statutory services to take over. Patient seen at home. admitted on a section. Over a period of a year has been admitted twice to hospital after noncompliance with medication.

(ii) Chronic schizophrenic. Patient has been known to services for many years and lives in a group home. She occasionally relapses when she discontinues her depot injection, and community psychiatric nurses provide most of the clinical input.

(iii) Manic depressive. Has regular hypomanic swings despite being on lithium salts. Occasionally these swings become extreme and require admission to hospital.

\section{(b) Neurotic}

An agoraphobic middle-aged housebound woman, with occasional bouts of depression and marital difficulties. We are assuming that she will not require admission to hospital.

\section{(c) Personality disorder}

An inadequate man in his late 20 s finding himself regularly getting into fights as a result of drunken behaviour. Occasionally experiences brief psychotic-type experiences. Has been in prison for violent offences.

\section{Patient clinical times}

In this part of the exercise, we are including the time it is predicted that the consultant will 
be involved in the management of the patient over a period of a year.

(a) (i) Young schisophrenic patient

\begin{tabular}{|c|c|c|}
\hline & $\begin{array}{l}\text { Ideal } \\
\text { (hours) }\end{array}$ & $\begin{array}{l}\text { Nlternative } \\
\text { (hours) }\end{array}$ \\
\hline \multicolumn{2}{|l|}{ Domiciliary vists and home } & 3 \\
\hline Letters & 2.5 & 2.5 \\
\hline Phone calls & 4 & 2 \\
\hline Case presentation $\times 2$ & 1 & 1 \\
\hline \multicolumn{3}{|l|}{ Ward round time } \\
\hline 1st admission 8 weeks & 2 & 2 \\
\hline 2nd admission 4 weeks & 1 & 1 \\
\hline Patient and family meetings & 6 & 2 \\
\hline Managers/MHRT+reports & 4 & 4 \\
\hline Section 3 assessment & 1 & 1 \\
\hline $\begin{array}{l}\text { Section } 117 \text { pre-discharge } \\
\text { meeting } \times 2\end{array}$ & 2 & 2 \\
\hline Consent to treatment & 0.5 & 0.5 \\
\hline $\begin{array}{l}\text { Out-patient appointments } \\
\text { (inc. section } 117 \text { meetings) }\end{array}$ & 6 & 1 \\
\hline Total & 36 & 22 \\
\hline
\end{tabular}

Note. We estimate that most of these patients with this diagnosis are likely to require admissions under the Mental Health Act. A third are likely to require attendances at either or both mental health review tribunals (MHRTs) and managers' meetings.

If a patient does not apply to the MHRTs, or is informal and compliant with treatment over period of a year this figure can be reduced to 29 hours (14.5 hours in the alternative model).

A small percentage of patients, say $5-10 \%$, are likely to have dealings with the law, creating further forensic work, some requiring prison visits. Should they need to be placed on registers, they would require another hour long meeting.

(a) (ii) Well-known chronic schisophrenic (Same for ideal and alternattve models)

Out-patient appointments/reviews

Letters

Home assessments/Non hosp. setting

Letters

Phone calls

Total

Note. We estimate that $10 \%$ of these patients over a year are likely to experience acute schizophrenic breakdowns requiring admission, in which case these would demand approximately half as much time as acutely ill schizophrenic patients, i.e. 18 hours (9 hours); $20 \%$ are likely to become subacutely ill, without the need for admission, but concerted attempts to keep them in the community are likely to impose extra burdens on consultant staff, and we therefore estimate the same time, approximately 18 hours per patient per year. This would add approximately 4 hours to the 'average' patient in this category.

(a) (iii) Manic depresatve peychosis

$\begin{array}{lll}\text { Out-patient appointments } & \begin{array}{l}\text { Ideal } \\ \text { (hours) }\end{array} & \begin{array}{c}\text { Niternattve } \\ \text { (hours) }\end{array} \\ \begin{array}{l}\text { Domiciliary visit } \\ \text { Phone calls/planning }\end{array} & 2 & 2 \\ \text { Travel/coordination } & 2 & 2 \\ \begin{array}{l}\text { Letters } \\ \text { Case presentation }\end{array} & 3 & 2 \\ \text { Ward round time } & 0.5 & 1 \\ \quad \text { (admission 10 weeks/year) } & 2.5 & 0.5 \\ \begin{array}{l}\text { Patient and family meetings } \\ \text { Pre-discharge meeting }\end{array} & 3.5 & 1 \\ \begin{array}{l}\text { Section 3 assessment } \\ \text { Consent to treatment }\end{array} & 0.5 & 0.5 \\ \text { Section 117 \&/or pre- } & 0.5 & 0.5 \\ \quad \text { discharge meeting/s } & 2 & 0.5 \\ \text { MHRT/managers } & 3 & 3 \\ \text { Total } & 24.5 & 16.5\end{array}$

Note. We estimate that $50 \%$ of patients will present for admission with hypomanic/manic presentations where it is likely they will be on a section and appeal against their sections. For those who do not require sectioning, we estimate a reduction in time by 4.5 hours in the ideal model and 4 hours in the alternative model. A proportion will convert to depressive illnesses. The literature indicates that mixed affective disorders spend additional time in hospital.

(b) Neurotic patient

$\begin{array}{lll}\text { Ideal } & \begin{array}{l}\text { Alternative } \\ \text { (hours) } \\ \text { (hourv) } \\ \text { (same but seen }\end{array} \\ \text { Letters } & 1.5 & \text { by registrar) }\end{array}$

Out-patient appointments (seen once a month) Liaison with GP and other services 1

Total 10

(c) Personality disorder

\begin{tabular}{|c|c|c|}
\hline 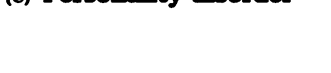 & $\begin{array}{l}\text { Ideal } \\
\text { (houry) }\end{array}$ & $\begin{array}{l}\text { Alternative } \\
\text { (hours) }\end{array}$ \\
\hline Assessment in prison & 3 & 3 \\
\hline Court reports/attendances & 3 & 3 \\
\hline Phone calls (solicitors, etc) & 2 & 2 \\
\hline Case presentation & 0.5 & 0.5 \\
\hline $\begin{array}{l}\text { Ward round } \\
\text { (admission } 4 \text { weeks) }\end{array}$ & 1 & 1 \\
\hline Patient/family meetings & 3.5 & 1 \\
\hline Pre-discharge meeting & 1 & 0.5 \\
\hline Court attendance & 4 & 4 \\
\hline Out-patient appointments & 3 & 1 \\
\hline Letters & 2 & 1 \\
\hline Total & 23 & 17 \\
\hline
\end{tabular}




\section{Case mix}

In summary, estimated times dedicated to patients over a period of a year with these diagnostic descriptions come to:

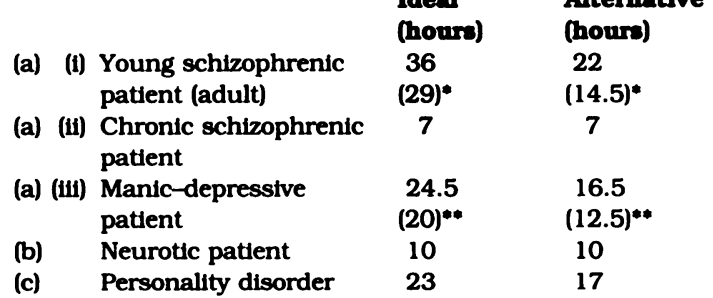

"Patients who do not apply to the MHRTs or are informal and compliant to treatment over a period of one year.

* Patients who do not require sectioning.

Most adult psychiatrists have a mix of cases under their care. Under current health reforms, purchasers, whether they be health authorities of GP fundholders, will have a greater say on the level and composition of this case mix.

In this exercise we have not addressed the added complications of co-morbidity, especially as far as abuse of alcohol and other drugs when associated with psychiatric illness. We expect that when co-morbidity is present, an addition of $20 \%$ should be estimated for consultant time.

\section{Example}

We must bear in mind that we are here referring to patients who are actively being looked after by the consultant at any one time. Many patients are likely to be on the 'books' but not demand consultant time, except for occasional reviews.

In the ideal model, assuming a consultant with a catchment area of 50000 in a deprived London borough admits at least 15 acute young schizophrenic patients over a period of one year, that these patients are admitted under a section of the Mental Health Act, and that four apply to MHRTs(*), fail to comply and are readmitted, the demand on time will be:

(*) $4 \times 36=144$ hours

$11 \times 29=319$ hours

Partial total $=453$ hours

In the alternative model, and keeping roughly to the same amount of hours, the consultant and his team will be able to look after 27 patients, seven of whom we estimate will require Mental Health Act work:

(*)7 $722=144$ hours

$20 \times 14.5=290$ hours

Partial total $=434$ hours
This scenario only allows the rest of the consultant's 372 hours of clinical time to be spent on patients with other conditions. Say:

\begin{tabular}{|c|c|c|}
\hline Acute schizophrenia & $\begin{array}{l}\text { Ideal } \\
15 \text { patients } \\
\text { (453 hours) }\end{array}$ & $\begin{array}{l}\text { Alternative } \\
27 \text { patients } \\
\text { (434 hours) }\end{array}$ \\
\hline Manic depression & $\begin{array}{c}3 \text { patients } \\
(3 \times 24.5= \\
73.5 \text { hours })\end{array}$ & $\begin{array}{c}5 \text { patients } \\
(5 \times 16.5= \\
82.5 \text { hours })\end{array}$ \\
\hline Chronic schizophrenia & $\begin{array}{c}29 \text { patients } \\
(29 \times 7= \\
203 \text { hours })\end{array}$ & $\begin{array}{c}29 \text { patients } \\
(29 \times 7= \\
203 \text { hours })\end{array}$ \\
\hline Neurosis & $\begin{array}{l}4 \text { patients } \\
(4 \times 10= \\
40 \text { hours })\end{array}$ & $\begin{array}{l}4 \text { patients } \\
(4 \times 10= \\
40 \text { hours })\end{array}$ \\
\hline \multirow[t]{2}{*}{ Personality disorder } & $\begin{array}{l}1 \text { patient } \\
(1 \times 23= \\
23 \text { hours })\end{array}$ & $\begin{array}{l}2 \text { patients } \\
(2 \times 17= \\
34 \text { hours })\end{array}$ \\
\hline & Ideal & Alternative \\
\hline Total clinical time (hours) & 792.5 & 793.5 \\
\hline Total caseload & $\begin{array}{l}52 \text { patients on } \\
\text { active } \\
\text { clinical list }\end{array}$ & $\begin{array}{l}67 \text { patients } \\
\text { plus those seen } \\
\text { by multidisci- } \\
\text { plinary team. }\end{array}$ \\
\hline
\end{tabular}

Locally, audit committees could test the validity of these estimates as they will clearly vary in different population-based practices. and will be influenced by the skill mix of multtdisciplinary teams and the degree of development of specialist tertiary services in each district. Added to this, the advent of the care programme approach, supervision orders and registers will obviously impact on consultant's time.

\section{Acknowledgements}

We would like to thank all members of the Psychiatric Advisory Committee of the exNorth East Thames Region as well as Alaistair Scotland, Regional Medical Advisor, for their help in the preparation of this paper.

\section{References}

CREed, F. (1995) How consultants manage their time. Advances in Psychiatric Treatment, 1, 65-70.

GoldMan, R., FAULKNER, L. \& BREEDING, K. (1994) A method for estimating psychiatrist staffing needs in community mental health programmes. Hospital and Community Psychiatry. 45. 333-337.

WATSON, J. P. (1985) Psychiatric manpower and the works of the consultant. Bulletin of the Royal College of Psychiatrists, 9, 170-173.

- (1986) Calculating a district's psychiatric manpower. Bulletin of the Royal College of Psychiatrists, 10, 334-337.

*Leonard Fagin, Doris Hollander and Malcolm Weller, Psychiatric Advisory Committee, North East Thames Regional Health Authority, Claybury Hospital, Woodford Bridge, EssexIG8 8BY

*Correspondence 